\title{
Nedocromil sodium reduces cigarette smoke-induced bronchoconstrictor hyperresponsiveness to substance $P$ in the guinea-pig
}

\author{
D.J. Dusser, H. Lacroix, N. Desmazes-Dufeu, M. Mordelet-Dambrine, G.L. Roisman
}

Nedocromil sodium reduces cigarette smoke-induced bronchoconstrictor hyperresponsiveness to substance $P$ in the guinea-pig. D.J. Dusser, H. Lacroix, N. Desmazes-Dufeu, M. Mordelet-Dambrine, G.L. Roisman. (CERS Journals Ltd 1995.

ABSTRACT: Acute exposure to cigarette smoke provokes airway hyperresponsiveness to substance $P$ and inactivates neutral endopeptidase (NEP). To determine whether nedocromil sodium can prevent cigarette smoke-induced hyperresponsiveness to substance $P$, we studied two groups of anaesthetized guinea-pigs.

One group of guinea-pigs was pretreated with aerosolized $0.9 \% \mathrm{NaCl}$ solution (90 breaths), the other group was pretreated with aerosolized nedocromil sodium $\left(10^{-4} \mathrm{M}, 90\right.$ breaths $)$. In each animal, pretreatment was followed by either exposure to the smoke of one cigarette or exposure to air. After acute exposure to cigarette smoke or to air, we measured the change in total pulmonary resistance $\left(R_{L}\right)$ induced by increasing concentrations of aerosolized substance $P$.

In the absence of nedocromil sodium, the bronchoconstrictor responses to substance $P$ were greater in cigarette smoke-exposed guinea-pigs than in air-exposed animals. Aerosolized nedocromil sodium had no effect on the response to substance $\mathbf{P}$ in airexposed animals, but it reduced cigarette smoke-induced hyperresponsiveness to substance $P$. The preventive effect on cigarette smoke-induced hyperresponsiveness to substance $P$ was observed at concentrations of aerosolized nedocromil sodium of $3 \times 10^{-5}, 10^{-4}$, and $3 \times 10^{-4} \mathrm{M}$. In vitro, cigarette smoke solution inhibited NEP activity from lung membrane preparations, but this inhibitory effect was not modified by nedocromil sodium $\left(10^{-4} \mathrm{M}\right)$.

We conclude that aerosolized nedocromil sodium reduces cigarette smoke-induced airway hyperresponsiveness to substance $P$ in vivo. This action of nedocromil sodium is not due to a protective effect on cigarette smoke-induced inactivation of NEP in vitro. Eur Respir J., 1995, 8, 47-52.
Service de Pneumologie, U.F.R. CochinPort-Royal, Université René Descartes, Paris, France.

Correspondence: D.J. Dusser

Service de Pneumologie

Hôpital Cochin

27, rue du Fg Saint Jacques

75014 Paris

France

Keywords: Airway hyperresponsiveness cigarette smoke

nedocromil sodium

neutral endopeptidase

substance P

Received: July 301993

Accepted for publication October 101994

This study was supported by a grant from Fisons Laboratories. HL was supported in part by a grant from Fabriques de Tabac Réunies.
Like many other irritants, cigarette smoke is a potent stimulant of airway sensory nerves, which provoke neurogenic inflammation in the airway by releasing endogenous tachykinins [1-3]. We have recently shown in guinea-pigs that exposure to cigarette smoke induces airway hyperresponsiveness to substance $\mathrm{P}(\mathrm{SP})$, and that this hyperresponsiveness is associated with inactivation of airway neutral endopeptidase (NEP) [4], a peptidase known to be a major modulator of tachykinin-induced effects in the airway [5]. The effects of cigarette smoke exposure on the response to tachykinins, combined with its stimulating action on the release of tachykinins by sensory nerves, are likely to play a major role in the production of tobacco smoke-induced inflammation in the airways. Drugs that may reduce airway hyperresponsiveness to tachykinins may be important for preventing cigarette smoke-induced airway inflammation.

Nedocromil sodium is known to inhibit the bronchoconstrictor response to antigen [6], cold air [7], exercise [8], adenosine [9], distilled water [10], and hyperosmolar saline [11]. These stimuli are thought to exert their effects largely through inflammatory mediators. In humans, nedocromil sodium is also known to inhibit response to challenges which involve activation of neuronal reflexes, such as sulphur dioxide [12], metabisulphite [13], bradykinin [14], neurokinin A [15], and substance $P$ [9]. Nedocromil sodium does not affect SP-induced smooth muscle contraction in guinea-pig airway in vitro; whereas the drug reduces nonadrenergic noncholinergicinduced bronchoconstrictor response by modulating the release of tachykinins from sensory nerves [16].

The aim of this study was to examine whether nedocromil sodium prevents cigarette smoke-induced increase in the bronchoconstrictor response to SP, and if so, whether this was due to a protective effect of nedocromil sodium on cigarette smoke-induced inactivation of airway NEP.

\section{Methods}

Animals

Specific pathogen-free (SPF) male Hartley-outbred guinea-pigs (Charles River France) weighing 320-400 g were used in this study. 


\section{Studies in vivo}

Measurement of total pulmonary resistance $\left(R_{L}\right)$. Animals were anaesthetized with $80 \mathrm{mg} \cdot \mathrm{kg}^{-1}$ thiopental sodium given intraperitoneally (i.p.), and placed under a homeothermic blanket $\left(38^{\circ} \mathrm{C}\right)$. Every $30 \mathrm{~min}$, additional injections of thiopental sodium $\left(10 \mathrm{mg} \cdot \mathrm{kg}^{-1} i . p\right.$. $)$ were given. The level of anaesthesia was monitored on the aspect of the airflow and the transpulmonary pressure signals (see below) during the respiratory cycle. A polyethylene catheter was introduced into the right carotid artery to measure arterial blood gases and $\mathrm{pH}$. Animals were artificially ventilated via a tracheal cannula with a constant-volume respirator (model 683, Harvard Apparatus, South Natick, MA, USA), at a frequency of 90 breaths $\cdot \mathrm{min}^{-1}$.

Tidal volume was adjusted so that mean \pm SEM arterial blood gases obtained through the catheter placed in the carotid artery were as follows: arterial oxygen tension $\left(\mathrm{PaO}_{2}\right) 14.1 \pm 0.5 \mathrm{kPa}(106 \pm 3.9 \mathrm{mmHg})$, arterial carbon dioxide tension $\left(\mathrm{PaCO}_{2}\right) 5.7 \pm 0.1 \mathrm{kPa}(43+0.9 \mathrm{mmHg})$ and $\mathrm{pH}$ 7.3-7.4. Airflow was monitored continuously using a pneumotachograph (Fleisch No. 000; Richmond, VA, USA) connected to a differential pressure transducer (model DP45, Validyne Engineering Corp., Northridge, CA, USA). Tidal volume was obtained by electrical integration of airflow.

A fluid-filled polyethylene catheter was introduced into the oesophagus to measure oesophageal pressure, as an approximation of pleural pressure. Intratracheal pressure was measured with a catheter connected to the tracheal cannula. The oesophageal and the tracheal catheters were connected to a differential pressure transducer (model No. 267 AC, Hewlett-Packard Co., Palo Alto, CA, USA) which gave the transpulmonary pressure, defined as the pressure difference between the intratracheal and the oesophageal pressures. Output signals representing airflow, tidal volume and transpulmonary pressure were amplified using Validyne amplifiers (model CD19 A). These signals were continuously visualized on a computer screen and were recorded on a polygraph recorder (Gould, model ES 1000). Total pulmonary resistance $\left(\mathrm{R}_{\mathrm{L}}\right)$ was calculated using the method of AMDUR and MEAD [17].

Aerosols of drugs (mass median aerodynamic diameter $1.0 \mu \mathrm{m}$; geometric standard deviation 1.3) were generated by an ultrasonic nebulizer (model 99, De Vilbiss, Somerset, PA, USA).

Cigarette smoke exposure. Cigarette smoke was collected in a polypropylene syringe at a rate of 1 puff. $\mathrm{min}^{-1}$ (each puff $2 \mathrm{~s}$ duration, $30 \mathrm{ml}$; total of $8-10$ puffs per cigarette) to a final butt length of $20 \mathrm{~mm}$. The smoke was then slowly expelled in the inspiratory circuit of the ventilator. Thus, each puff of cigarette smoke was diluted in air by approximately $1 / 5$, and was delivered to the animal during $30 \mathrm{~s}$ intervals followed by $30 \mathrm{~s}$ with air ventilation.

Effects of nedocromil sodium on cigarette smoke-induced bronchoconstrictor response to SP. To determine the effect of nedocromil sodium on cigarette smoke-induced bronchoconstrictor response to SP, we studied two groups of animals. One group of guinea-pigs received aerosolized $0.9 \% \mathrm{NaCl}$ solution ( 90 breaths), followed $5 \mathrm{~min}$ later by exposure to the smoke of one cigarette, or exposure to air given in the same conditions as for cigarette smoke exposure. The other group of animals received aerosolized nedocromil sodium $\left(10^{-4} \mathrm{M}, 90\right.$ breaths $)$, followed $5 \mathrm{~min}$ later by exposure either to the smoke of one cigarette, or to air given in the same conditions as for cigarette smoke exposure. The bronchoconstrictor response to SP was determined $30 \mathrm{~min}$ after exposure to air or to cigarette smoke using the following protocol. After an initial challenge with $0.9 \% \mathrm{NaCl}$ (15 breaths), we measured the change in RL induced by increasing concentrations of aerosolized SP $\left(10^{-6}, 10^{-5}, 3.2 \times 10^{-5}\right.$, and $10^{-4} \mathrm{M} ; 15$ breaths at each concentration). Each successive concentration of SP was delivered after RL had reached a stable value. Responses were evaluated as the maximum $R_{L}$ value after each concentration of SP.

Dose-dependent effect of nedocromil sodium on cigarette smoke-induced bronchoconstrictor response to SP. We studied the effect of various concentrations of aerosolized nedocromil sodium on cigarette smoke-induced bronchoconstrictor response to SP. Animals received aerosolized nedocromil sodium at concentrations varying from $10^{-6} \mathrm{M}$ to $3 \times 10^{-4} \mathrm{M}$ (90 breaths at each concentration) or aerosolized $0.9 \% \mathrm{NaCl}$ (90 breaths). Pretreatment with nedocromil sodium or $0.9 \% \mathrm{NaCl}$ was followed 5 min later by exposure to the smoke of one cigarette. We measured $R_{L}$ in response to increasing concentrations of aerosolized SP $\left(10^{-6}, 10^{-5}, 3.2 \times 10^{-5}\right.$, and $10^{-4} \mathrm{M} ; 15$ breaths at each concentration) $30 \mathrm{~min}$ after being exposed to cigarette smoke. Each concentration of nedocromil sodium was studied in different animals.

In each study described above, administration of pretreatment with $0.9 \% \mathrm{NaCl}$ or nedocromil sodium at various doses was randomly chosen. Responses were evaluated as maximum RL level after each dose of SP.

\section{Studies in vitro}

Lung membrane preparation. Guinea-pigs were killed by cervical dislocation and exsanguinated. The pulmonary circulation was perfused with a $0.9 \% \mathrm{NaCl}$ to remove contaminating blood. Lungs were removed and kept on ice until used. Tissues were weighed, then homogenized in $15 \mathrm{vol}$ of ice cold $0.05 \mathrm{M}$ Tris- $\mathrm{HCl} 0.25 \mathrm{M}$ saccharose buffer ( $\mathrm{pH} 7.4$ ) with a blender (3 times $15 \mathrm{~s}$ ). The homogenate was centrifuged at $1,000 \times \mathrm{g}$ for $8 \mathrm{~min}$ at $4^{\circ} \mathrm{C}$. The resulting supernatant fraction was centrifuged at $45,000 \times \mathrm{g}$ for $10 \mathrm{~min}$ at $4^{\circ} \mathrm{C}$ to yield a cell membrane pellet which was then resuspended in the Trissaccharose buffer. The cell membrane fraction was immediately frozen in liquid nitrogen and stored at $-80^{\circ} \mathrm{C}$, for later determination of NEP activity.

Measurement of NEP-like activity. Determination of NEP activity was performed using the enkephalin degradation method of LLORENS et al. [18]. Briefly, the tissues 
were diluted as necessary in assay buffer containing 125 $\mathrm{mM} \mathrm{NaCl}, 50 \mathrm{mM}$ hydroxyethylpiperazine ethanesulphonic acid (HEPES) buffer, $\mathrm{pH}$ 7.4. Duplicate samples of $50 \mu \mathrm{l}$ of homogenates were incubated at $37^{\circ} \mathrm{C}$ for 40 min with ${ }^{3} \mathrm{H}-\mathrm{Tyr}, \mathrm{D}-\mathrm{Ala}^{2}$-leucine enkephalin $(20 \mathrm{nM}$, final volume $100 \mu \mathrm{l})$. Phosphoramidon $\left(10^{-6} \mathrm{M}\right)$, a potent inhibitor of NEP [19], was added to parallel duplicate samples. Blanks were obtained by using assay buffer $(50 \mu \mathrm{l})$ instead of lung membrane preparation under identical experimental conditions. Cleaved ${ }^{3} \mathrm{H}-\mathrm{Tyr}, \mathrm{D}-$ Ala ${ }^{2}$-leucine enkephalin was separated chromatographically from uncleaved substrate, and was counted in a scintillation counter. NEP-like activity was assessed by calculating the ratio of cleaved substrate to total ${ }^{3} \mathrm{H}$-Tyr,D-Ala ${ }^{2}$-leucine enkephalin under conditions of initial velocity. Substrate degradation inhibited by phosphoramidon $10^{-6} \mathrm{M}$ was considered specific for NEP-like activity.

Preparation of cigarette smoke solution. A water soluble extract of cigarette smoke (gas-phase) was prepared as follows. The smoke from two cigarettes was collected through a Cambridge filter pad in a polypropylene syringe at a rate of 1 puff. $\mathrm{min}^{-1}$ (each puff, $2 \mathrm{~s}$ duration, $30 \mathrm{ml}$; total of $8-10$ puffs per cigarette) to a final butt length of $20 \mathrm{~mm}$. Each puff of cigarette was bubbled slowly through the assay buffer solution $(125 \mathrm{mM} \mathrm{NaCl}$, $50 \mathrm{mM}$ HEPES buffer, $\mathrm{pH}$ 7.4) to obtain a concentration of smoke solution of 2 cigarettes $3 \mathrm{ml}^{-1}$. The smoke solution was then titrated to $\mathrm{pH}$ 7.4. The resulting smoke solutions were kept on ice and were used within 30 min following their preparation.

Effect of nedocromil sodium on cigarette smoke solutioninduced inactivation of NEP-like activity of lung cell membranes. The cleavage of ${ }^{3} \mathrm{H}-\mathrm{Ty}, \mathrm{D}-\mathrm{Ala}^{2}$-leucine enkephalin by lung membrane preparations $(50 \mu \mathrm{l})$ was determined after a preincubation for $15 \mathrm{~min}$ at room temperature with cigarette smoke solution (2 cigarettes per $3 \mathrm{ml})$ or with assay buffer $(25 \mu \mathrm{l})$ in the presence or absence of $10^{-4} \mathrm{M}$ nedocromil sodium.

\section{Reagents}

We used commercial cigarettes, Gauloises (Seita, France). Each cigarette contained $16.9 \mathrm{mg}$ tar and 1.31 mg nicotine.

Drugs and chemicals were obtained from the following sources: substance P, phosphoramidon (Peninsula Labs, Merseyside, UK); nedocromil sodium (Fisons Labs Ltd, Loughborough, UK); ${ }^{3} \mathrm{H}-\mathrm{Tyr}, \mathrm{D}-\mathrm{Ala}^{2}$-leucine encephalin (CEA, Gif-sur-Yvette, France). All drugs for in vivo studies were prepared in $0.9 \% \mathrm{NaCl}$ solution on the day of experiment.

\section{Statistical analysis}

Data are expressed as mean \pm SEM. Two-way analysis of variance (ANOVA) was used to compare mean values of $\mathrm{RL}_{\mathrm{L}}$ for the effects of pretreatment (air exposure and cigarette exposure, with or without nedocromil sodium) and for the effects of various concentrations of nedocromil sodium on the concentration-response curves to SP. We used a multiple contrasts method (Scheffe's test) to compare the effects of different pretreatments, and the effects of different concentrations of nedocromil sodium on the concentration-response curves to SP. $\mathrm{RL}_{\mathrm{L}}$ values before SP challenge and after initial challenge with $0.9 \% \mathrm{NaCl}$ solution were compared with a one-way ANOVA. Pairwise comparisons between NEP activities in lung membrane preparations incubated with or without cigarette smoke solution in the presence or absence of nedocromil sodium were made by paired t-tests.

\section{Results}

\section{Studies in vivo}

Effects of nedocromil sodium on cigarette smoke-induced bronchoconstrictor response to SP. Before SP challenge, baseline $\mathrm{RL}_{\mathrm{L}}$ values in animal pretreated with aerosolized $0.9 \% \mathrm{NaCl}$ followed by exposure to air or to cigarette smoke $\left(0.13 \pm 0.02\right.$ and $0.18 \pm 0.02 \mathrm{cmH}_{2} \mathrm{O} \cdot \mathrm{ml}^{-1} \cdot \mathrm{s}$, respectively) or in animals pretreated with aerosolized nedocromil sodium $\left(10^{-4} \mathrm{M}\right)$ followed by exposure to air or to cigarette smoke $(0.17 \pm 0.03$ and $0.15 \pm 0.02$ $\mathrm{cmH}_{2} \mathrm{O} \cdot \mathrm{ml}^{-1} \cdot \mathrm{s}$, respectively) were not different from one another $(\mathrm{p}>0.3)$. After initial challenge with $0.9 \% \mathrm{NaCl}$ (15 breaths), RL values were similar in the different groups of animals (fig. 1) ( $>0.3)$.

After pretreatment with aerosolized $0.9 \% \mathrm{NaCl}$, the response to SP was greater in animals that were exposed to smoke exposure than in animals exposed to air $(\mathrm{p}<0.001)$. Aerosolized nedocromil sodium by itself had no effect on the response to SP, since after exposure to air the concentration-response relationship to SP were similar in animals pretreated with nedocromil sodium and those pretreated with $0.9 \% \mathrm{NaCl}(\mathrm{p}>0.7)$. As compared to animals pretreated with $0.9 \% \mathrm{NaCl}$, pretreatment with nedocromil sodium $\left(10^{-4} \mathrm{M}\right)$ reduced cigarette smokeinduced response to SP $(\mathrm{p}<0.002)$. Pretreatment with nedocromil sodium did not completely abolish cigarette smoke-induced hyperresponsiveness to SP, since after pretreatment with nedocromil sodium, the response to SP in animals exposed to cigarette smoke was still slightly greater than in animals exposed to air $(\mathrm{p}<0.03)$.

Dose-dependent effect of nedocromil sodium on cigarette smoke-induced bronchoconstrictor response to SP. Aerosolized nedocromil sodium at various concentrations $\left(10^{-6}\right.$ to $\left.3 \times 10^{-4} \mathrm{M}\right)$ had no effect on prechallenge RL values $(p>0.3)$ and on the RL values observed after initial challenge with aerosolized $0.9 \% \mathrm{NaCl}$ ( 15 breaths) $(\mathrm{p}>0.3)$ (fig. 2).

Aerosolized nedocromil sodium at concentrations equal or superior to $3 \times 10^{-5} \mathrm{M}$ induced a shift to the right of the concentration-response relationship to SP in cigarette smoke-exposed animals $(\mathrm{p}<0.001)$. However, after nedocromil sodium at concentrations of $3 \times 10^{-5}, 10^{-4}$, and 


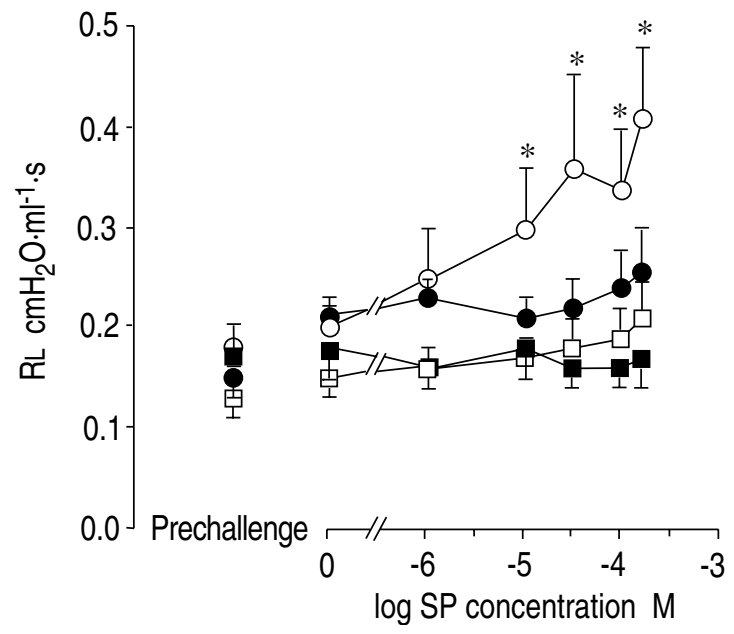

Fig. 1. - Concentration-response relationship to aerosolized substance P (SP) (15 breaths at each concentration) $30 \mathrm{~min}$ after exposure to air (squares) or after exposure to the smoke from one cigarette (circles) in anaesthetized guinea-pigs. Prior $(5 \mathrm{~min})$ to exposure to air or to cigarette smoke, animals were pretreated ( 90 breaths) either with aerosolized nedocromil sodium $\left(10^{-4} \mathrm{M}\right.$, closed symbols) or with $0.9 \%$ $\mathrm{NaCl}$ (open symbols). Each curve represents data collected from 6-8 different animals. Total pulmonary resistance $\left(\mathrm{RL}_{\mathrm{L}}\right)$ is expressed (mean $\pm \mathrm{SEM}$ ) as $\mathrm{cmH}_{2} \mathrm{O} \cdot \mathrm{ml}^{-1} \cdot \mathrm{s}$. ${ }^{*}: \mathrm{p}<0.001$ smoke-exposed $v s$ air-exposed.

$3 \times 10^{-5} \mathrm{M}$ the concentration-response relationship to SP were not different from one another (each comparison, $\mathrm{p}>0.7)$. Therefore, although the reduction of cigarette smoke-induced hyperresponsiveness to SP was observed with the three highest concentrations of nedocromil sodium, we were unable to actually demonstrate a concentrationdependent effect of this drug.

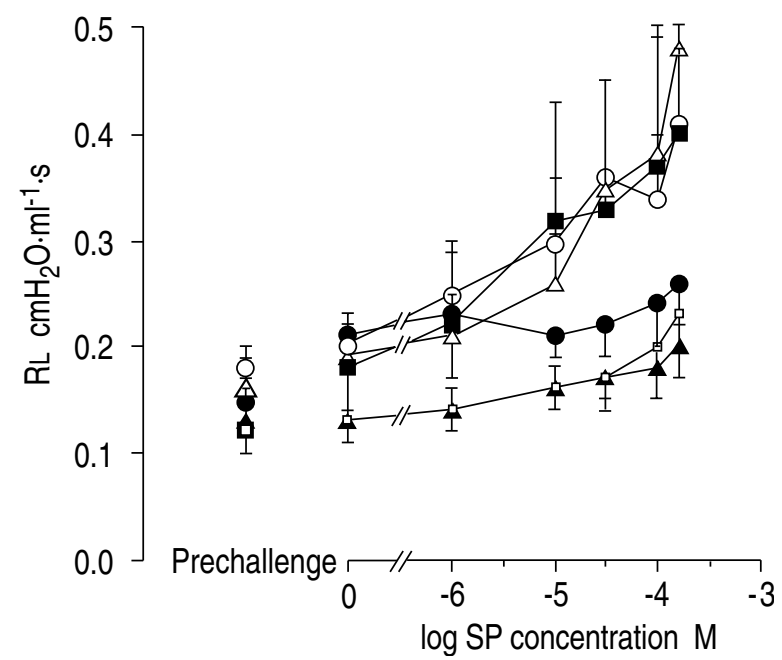

Fig. 2. - Effects of pretreatment with aerosolized $0.9 \% \mathrm{NaCl}(90$ breaths) or aerosolized nedocromil sodium at various concentrations ( $10^{-6}$ to $3 \times 10^{-4} \mathrm{M}$ for $15 \mathrm{~min}$; each concentration, 90 breaths) on the concentration-response relationship to aerosolized substance P (SP) (15 breaths at each concentration) in anaesthetized guinea-pigs that were exposed to cigarette smoke. Increase in total pulmonary resistance ( RL) is expressed (meantsEM) as $\mathrm{cmH}_{2} \mathrm{O} \cdot \mathrm{ml}^{-1} \cdot \mathrm{s}$. Each concentration of nedocromil sodium was administered to eight separate animals. $O$ : $0.9 \% \mathrm{NaCl}+$ smoke; $\Delta$ : nedocromil $\left(10^{-6} \mathrm{M}\right)+$ smoke; $:$ nedocromil $\left(10^{-5} \mathrm{M}\right)+$ smoke; $\boldsymbol{\Delta}:$ nedocromil $\left(3 \times 10^{-5} \mathrm{M}\right)+$ smoke; $\bullet$ : nedocromil $\left(10^{-4} \mathrm{M}\right)+$ smoke; $\square:$ nedocromil $\left(3 \times 10^{-4} \mathrm{M}\right)+$ smoke.

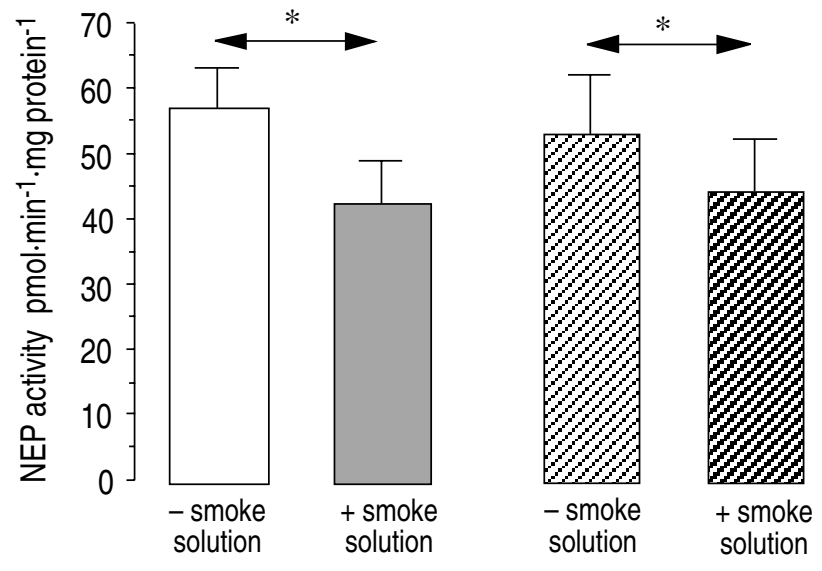

Fig. 3. - Effects of smoke solution (2 cigarettes $\left.3 \mathrm{ml}^{-1}\right)$ obtained from filtered (gas-phase) cigarettes on the activity of neutral endopeptidase (NEP) in guinea-pig lung membrane preparation in the presence or absence of nedocromil sodium $\left(10^{-4} \mathrm{M}\right)$. Smoke solution or assay buffer was preincubated with lung membrane preparation for $15 \mathrm{~min}$ before measurement of NEP activity. Each bar represents the data collected from six animals. Neutral endopeptidase activity is expressed (mean \pm SEM) as the percentage of the cleavage (inhibitable by phosphoramidon) of ${ }^{3} \mathrm{H}-\mathrm{Tyr}, \mathrm{D}-\mathrm{Ala}^{2}$-leucine enkephalin by lung membrane preparation in the absence of smoke solution. Smoke solution induced a decrease in NEP activity that was similar in the presence or absence of nedocromil sodium (each, $\mathrm{p}<0.03$ ).

\section{Studies in vitro}

Effect of nedocromil sodium on cigarette smoke solutioninduced inactivation of NEP-like activity in lung membrane preparations. The cleavage of ${ }^{3} \mathrm{H}-\mathrm{Tyr}, \mathrm{D}-\mathrm{Ala}^{2}$-leucine enkephalin by normal guinea-pig lung cell membrane preparations in the absence or presence of nedocromil sodium $\left(10^{-4} \mathrm{M}\right)\left(57.4 \pm 6.1\right.$ and $53.5 \pm 9.0 \mathrm{pmol} \cdot \mathrm{min}^{-1} \cdot \mathrm{mg}$ protein $^{-1}$, respectively) was not different ( $\left.p>0.4\right)$. In lung membrane preparations exposed to cigarette smoke solution ( 2 cigarettes $\cdot 3 \mathrm{ml}^{-1}$ ) in the absence or presence of nedocromil sodium $\left(10^{-4} \mathrm{M}\right)$, the cleavage of ${ }^{3} \mathrm{H}$ Tyr,D-Ala ${ }^{2}$-leucine enkephalin $(42.6 \pm 7.0$ and $44.5 \pm 8.0$ $\mathrm{pmol} \cdot \mathrm{min}^{-1} \cdot \mathrm{mg}_{\text {protein }}{ }^{-1}$, respectively) were significantly reduced when compared to that in membrane preparations not exposed to cigarette smoke $(p<0.03$ in each condition). However, nedocromil sodium had no significant effect on the cleavage of ${ }^{3} \mathrm{H}-\mathrm{Tyr}, \mathrm{D}-\mathrm{Ala}^{2}$-leucine enkephalin by lung membrane preparation in the absence or in the presence of cigarette smoke solution ( $\mathrm{p}>0.4$, respectively) (fig. 3).

\section{Discussion}

Our results confirm our previous study showing that exposure to cigarette smoke leads to an enhanced bronchoconstrictor response to SP, an effect which was observed as soon as 15 min following smoke exposure [4]. Previous studies have shown that cigarette smoke causes an increase in vascular permeability in airway mucosa, by releasing endogenous tachykinins, as these effects were abolished when animals were pretreated with a tachykinin receptor antagonist, or when nerves were depleted of tachykinins 
by pretreatment with capsaicin [1-3]. In addition to the gas-phase of the smoke, nicotine, another important component of cigarette smoke, causes smooth muscle contraction by releasing SP [20]. Therefore, in addition to inducing neurogenic inflammation, cigarette smoke also provokes hyperresponsiveness to SP. The combination of these two effects is a possible mechanism by which cigarette smoke can exacerbate tachykinin-induced effects; and, thereby, induce an increase in mucus secretion [21], and airway inflammation [22].

Our study showed that nedocromil sodium given by inhalation prior to cigarette smoke exposure reduced the cigarette smoke-induced hyperresponsiveness to SP. The effect of aerosolized nedocromil was observed at concentrations much lower (approximately 50-150 times smaller) than that used in other studies in vivo [23]. Although the protective effect of nedocromil sodium on cigarette smoke-induced hyperresponsiveness to SP was demonstrated at three different concentrations $(3 \times$ $10^{-5} \mathrm{M}, 10^{-4} \mathrm{M}$, and $3 \times 10^{-4} \mathrm{M}$ ) we could not demonstrate a dose-dependent effect of this drug.

The mechanisms whereby nedocromil sodium reduces cigarette smoke-induced hyperresponsiveness is unclear. Indirect evidence suggests that nedocromil sodium does not affect tachykinin receptors on airway smooth muscle, because the drug does not modify the dose response curve to exogenous SP on tracheal smooth muscle [16]. We cannot exclude the possibility that, in vivo, nedocromil may affect the increase in airway vascular leakage induced by SP that may participate in the bronchoconstrictor effect of the neuropeptide. Such a hypothesis is supported by the finding that in human skin sodium cromoglycate, a drug close to nedocromil sodium, caused a dose-dependent inhibition of SP and neurokinin B-induced oedema [24]. However, we believe that this hypothesis is unlikely in the guinea-pig airway as nedocromil was shown to have no effect on airway microvascular leakage induced by release of endogenous neuropeptides from capsaicin-sensitive nerves [25].

SP is rapidly degraded by a membrane-bound peptidase, neutral endopeptidase (E.C. 3.4.24.11), that is present in several tissues in the airways, including epithelial cells, smooth muscle, submucosal glands, and nerves [5]. We have previously shown that smoke-induced hyperresponsiveness to SP was likely to be explained by inhibiton of airway NEP; additionally, we showed that cigarette smoke-induced inactivation of airway NEP was the consequence of either free radicals present in the smoke itself or the production of free radicals by activation of inflammatory cells induced by cigarette smoke exposure [4] or both. This conclusion was supported by the finding that superoxide dismutase dramatically reduced cigarette smoke-induced hyperresponsiveness to SP in vivo [4]. Previous studies indicated that smoke solutions prepared in a similar manner are capable of generating oxidants for several hours [26, 27], and may exert a direct inhibitory effect on airway NEP activity [4]. Therefore, we examined the possibility that nedocromil sodium could prevent inactivation of airway NEP due to free oxidizing radicals present in gas phase of cigarette smoke solution. Our results showed that nedocromil sodium had no effect on smoke-induced inactivation of NEP in vitro.

Exposure to cigarette smoke has been shown to result in activation of phagocytes [28]. When activated, these phagocytes produced large quantities of free radicals [29]. Nedocromil sodium is known to block activation of several inflammatory cells, such as human granulocytes [30-32], and to inhibit the release of free radicals from activated monocytes and platelets [33]. Nedocromil sodium is also capable of blocking smokeinduced release of neutrophil chemotactic activity from bovine epithelial cells [34]. In vivo studies have also shown nedocromil sodium to inhibit cigarette smokeinduced hyperreactivity to histamine and the concomitant inflammatory response [23]. Therefore, the protective effect of nedocromil sodium in the present study could be the consequence of reduced influx and/or activation of inflammatory cells in the airway.

In conclusion, we have demonstrated that nedocromil sodium prevents cigarette smoke-induced hyperresponsiveness to SP. By preventing activation of several inflammatory cells, some of which are involved in cigarette smoke-induced inflammation, and by blocking smokeinduced hyperresponsiveness to substance $\mathrm{P}$, nedocromil sodium may be a useful drug to prevent certain aspects of airway inflammation that occur after cigarette smoke exposure.

\section{References}

1. Lundberg JM, Saria A. Capsaicin-induced desensitization of airway mucosa to cigarette smoke, mechanical and chemical irritants. Nature 1983; 302: 251-253.

2. Lundberg JM, Martling CR, Saria A, Folkers K, Rosell S. Cigarette smoke-induced airway oedema due to activation of capsaicin-sensitive vagal afferents and substance P release. Neuroscience 1983; 10: 1361-1368.

3. Lundberg J, Lundblad L, Saria A, Änggård A. Inhibition of cigarette smoke-induced oedema in the nasal mucosa by capsaicin pretreatment and a substance $\mathrm{P}$ antagonist. Naunyn Sch Arch Pharmacol 1984; 326: 181-185.

4. Dusser DJ, Djokic TD, Borson DB, Nadel JA. Cigarette smoke induces bronchoconstrictor hyperresponsiveness to substance $\mathrm{P}$ and inactivates airway neutral endopeptidase in the guinea-pig: possible role of free radicals. J Clin Invest 1989; 84: 900-906.

5. Nadel J. Neutral endopeptidase modulates neurogenic inflammation. Eur Respir J 1991; 4: 745-754.

6. Youngchaiyud P, Lee T. A double-blind, cross-over trial comparing nedocromil sodium with placebo in bronchial antigen challenge tests. Eur J Respir Dis 1986; 69 (Suppl. 147): 302-304.

7. Del Bono L, Dente F, Patalano F, Del Bono N. Protective effect of nedocromil sodium and sodium cromoglycate on bronchospasm induced by cold air. Eur J Respir Dis 1986; 69 (Suppl. 147): 268-270.

8. Konig P, Hordvik N, Kreutz C. The preventive effect and duration of action of nedocromil sodium and cromolyn sodium on exercise-induced asthma (EIA) in adults. $J$ Allergy Clin Immunol 1987; 79: 64-68.

9. Crimini N, Palermo F, Olivieri R, et al. Effect of nedocromil on bronchospasm induced by inhalation of substance $\mathrm{P}$ in asthmatic subjects. Clin Allergy 1988; 18: $375-382$. 
10. Robuschi M, Vaghi A, Simone P, Bianco S. Prevention of fog-induced bronchospasm by nedocromil sodium. Clin Allergy 1987; 17: 69-74.

11. Rodwell L, Anderson S, Du Toit J, Seale J. Nedocromil sodium inhibits the airway response to hyperosmolar challenge in patients with asthma. Am Rev Respir Dis 1992; 146: 1149-1155.

12. Dixon C, Fuller R, Barnes P. Effect of nedocromil sodium on sulphur dioxide induced bronchoconstriction. Thorax 1987; 42: 462-465.

13. Wright W, Zhang Y, Salome C, Woolcock A. Effect of inhaled preservatives on asthmatic subjects. 1. Sodium metabisulfite. Am Rev Respir Dis 1990; 141: 1400-1404.

14. Dixon C, Barnes P. Bradykinin-induced bronchoconstriction: inhibition by nedocromil sodium and sodium cromoglycate. Br J Pharmacol 1989; 27: 831-836.

15. Joos G, Pauwells R, Van der Straeten M. The effect of nedocromil sodium on the bronchoconstrictor effect of neurokinin A in subjects with asthma. J Allergy Clin Immunol 1989; 83: 663-668.

16. Verleden G, Belvisi M, Stretton C, Barnes P. Nedocromil sodium modulates nonadrenergic, noncholinergic bronchoconstrictor nerves in guinea-pig airways in vitro. Am Rev Respir Dis 1991; 143: 114-118.

17. Amdur MO, Mead J. Mechanics of respiration in unanesthetized guinea-pigs. Am J Physiol 1958; 192: 364-368.

18. Llorens CB, Malfroy B, Schwartz JC, et al. Enkephalin dipeptidyl carboxypeptidase (enkephalinase) activity: selective radioassay, properties, and regional distribution in human brain. J Neurochem 1982; 39: 1081-1089.

19. Hudgin RL, Charleson SE, Zimmerman M, Mumford R, Wood PL. Enkephalinase: selective peptide inhibitors. Life Sci 1981; 29: 2593-2601.

20. Kizawa Y, Takayanagi I. Possible involvement of substance $\mathrm{P}$ immunoreactive nerves in the mediation of nicotine-induced contractile responses in isolated guineapig bronchus. Eur J Pharmacol 1985; 113: 319-323.

21. Gashi AA, Borson DB, Finkbeiner WE, Nadel JA, Basbaum CB. Neuropeptides degranulate serous cells of ferret tracheal glands. Am J Physiol 1986; 251 (Cell Physiol 20): C223-C229.

22. McDonald DM. Respiratory tract infections increase susceptibility to neurogenic inflammation in the rat trachea. Am Rev Respir Dis 1988; 137: 1432-1440.

23. Daffonchio L, Hernandez A, Omini C. Nedocromil sodium prevents airway hyperreactivity induced by cigarette smoke in anaesthetized guinea-pigs. Pulm Pharmacol 1992; 5: 19-21.

24. Crossman D, Dashwood M, Taylor G, Wellings R, Fuller R. Sodium cromoglycate: evidence of tachykinin antagonist activity in human skin. J Appl Physiol 1993; 75: 167-172.

25. Sakamoto T, Elwood W, Barnes P, Chung K. Pharmacological modulation of inhaled sodium metabisulphite-induced airway microvascular leakage and bronchoconstriction in the guinea-pig. Br J Pharmacol 1992; 107: 481-487.

26. Pryor WA, Prier DG, Church DF. Electron-spin resonance study of mainstream and sidestream cigarette smoke: nature of the free radicals in gas-phase smoke and in cigarette tar. Environ Health Perspect 1983; 47: 345355.

27. Pryor WA, Dooley MM, Church DF. Inactivation of human $\alpha_{1}$-proteinase inhibitor by gas-phase cigarette smoke. Biochem Biophys Res Commun 1984; 122: 676-681.

28. Janoff A, Pryor WA, Bengali ZH. Effects of tobacco smoke components on cellular and biochemical processes in the lung. Am Rev Respir Dis 1987; 136: 1058-1064.

29. Babior BM. Oxygen-dependent microbial killing by phagocytes. N Engl J Med 1978; 298: 659-668.

30. Devalia J, Sapsford R, Rusznak C, Davies R. The effect of human eosinophils on cultured human nasal epithelial cell activity and the influence of nedocromil sodium in vitro. Am J Respir Cell Mol Biol 1992; 7: 270-277.

31. Moqbel R, Walsh G, Kay A. Inhibition of human granulocyte activation by nedocromil sodium. Eur J Respir Dis 1986; 69 (Suppl. 147): 227-229.

32. Bruijnzeel P, Hamelink M, Kok P, Kreukniet J. Nedocromil sodium inhibits the A23187 and opsonised zymosan-induced leukotriene formation by human eosinophils but not human neutrophils. Br J Pharmacol 1989; 96: 631-636.

33. Thorel T, Joseph M, Tsicopoulos A, Tonnel A, Capron A. Inhibition by nedocromil sodium of IgE-mediated activation of human mononuclear phagocytes and platelets in allergy. Int Arch Allergy Appl Immunol 1988; 85: 232-237.

34. Ertl R, Koyama S, Von Essen S, Claassen L, Robins R, Rennard S. Nedocromil sodium reduces neutrophil chemotactic activity released by stimulated bovine bronchial epithelial cells. Am Rev Respir Dis 1990; 141: A173 (Abstract). 